\title{
Street Homes and Its Security Implications in Kumasi Metropolis-Ghana
}

\author{
Francess Dufie Azumah ${ }^{1}$ \\ ${ }^{1}$ Dr., Lecturer, Department of Sociology and Social Work, Kwame Nkrumah University of Science and Technology, \\ Ghana
}

Correspondence: Francess Dufie Azumah, Dr., Lecturer, Department of Sociology and Social Work, Kwame Nkrumah University of Science and Technology, Ghana.

Received: February 1, 2019

doi:10.11114/ijsss.v7i2.4094
Accepted: February 21, $2019 \quad$ Available online: February 26, 2019

URL: https://doi.org/10.11114/ijsss.v7i2.4094

\begin{abstract}
The study sought to identify the risk factors associated with street homes and the security implications of street homes. The study adopted a social survey design where a probability sampling, specifically the systematic sampling and simple random sampling techniques were used to select 200 respondents consisting of 120 children who lived in street homes, 60 parents who stayed in street homes and 20 police personnel. Interview questionnaire was the main tool for the data collection. Quantitative approach was used for the data analysis. The study found that risk factors associated with street homes included; victims of rape and sexual assault, engagement in all social vices, school drop-out, engagement in child labour, health problems, teenage pregnancy, victim of child prostitution, engagement in robbery and stealing, engagement in drug addiction, environmental pollution and influence by bad peers. Security personnel considered street homes as a major national security threat which had many security implications in the country; hence the researcher recommended that government should provide accommodation for parents who live in street homes with their family.
\end{abstract}

Keywords: street homes, child insecurity, national security

\section{Introduction}

Children are the future of every society. It is said that they are the prospect of every family and nation, yet many families and nations in the world have most children growing in street homes (Abari \& Audu, 2013). Children living in street homes are often handicapped, delinquent or are victims of all kinds of child abuse and neglect (Thomas, 2013). These children find themselves roaming in search for food, shelter, clothing and emotional comfort (Agenlli, 2016). UNICEF (2000) reported that street home children most of the time are children living in urban streets who spend most of their time on the street doing all manners of miniature jobs and serving as a source of shelter. Street home children may not necessary be children from broken homes, but studies suggest that some of these children come from strong, weak or have no family background (Alston, 2008). It is clear that most of these children from families living in street homes have no home/place of residence, little parental regulation and control, have no medical care, inadequate food supply and in some cases lack emotional stability (Annoh, 2012). Ennew (1994) defines street children as children who consider the street more than their family as their real home. It includes children who might not necessarily be homeless or without families, but children who live in situations where there is no protection, supervision, or direction from responsible adults (Ball, 2006). The family said to be the primary institution for children is required to fulfill the needs of children, including provision of food, clothing, security, love, shelter, health care, education and entertainment (Annoh, 2012). Moreover, the family is required to raise children in a cultural setting that passes the cultural values to them through socialization. The family is considered the reference point for the construction of children's norms, for the shaping of their personality and for their direction in life (ibid). However, most children lack the family unit and are left in the street. A study by UNICEF examined the consequence of children who lack the family unit and are left in the street. Some challenges according to UNICEF was that children who leave the family unit and find themselves in the street were ill-treated by strangers, abused by adults, engaged in criminal activities that had national security concerns (UNICEF, 2013).

Globally, in 2012, UNICEF estimated that over one hundred million children are living and growing in most streets in the urban areas around the world. Recently UNICEF reported that the actual number of children living and growing in the street is impossible to quantify but the figure for children living in the streets surely runs into tens of millions across the globe (UNICEF, 2013). The number is likely to increase in the coming years if nothing significant is done to curb the phenomenon of street children. Similarly, it is debatable as to whether the number of street children growing in the street 
globally has any security implications (Berezina, 2007). There is little awareness on the security threat of street children within the global societies over the years as the numbers of these children keep on increasing (Beck, 2009). While it is understandable that street children are victims of all kinds of social vices, and may become petty thieves, most studies do not extend the menace of street to the likelihood of these children growing to pose major global and national security threat (Benitez, 2007).

In Africa, the menace of street children is a major challenge to urban control (Bose, 2012). Many African countries have not be able to provide the precise number of children in the street but it is estimated that there are over one million street children in the major streets in most urban centers in African countries (Boswell, 2008). A study in Ethiopia revealed that most children spend on the average two to three hours working on the street before school and for another hour in the evening (UNICEF, 2012). For children who work on the street during weekends, $8 \%$ work for 8 to 10 hours. The average age at which children first become involved in street life in Ethiopia is 10.7 years (ibid). Although, there is not much reliable statistics on streets homes and the number of children living in street homes in Ghana, the situation of street children is not different in most cities and towns in Ghana comparing to other African countries and around the globe. The issue of street children had little talks about in Ghana until the 1990's (Chatterjee, 2012). The United States Information Service estimated that there are about fifty thousand of street children in Ghana (Hammond, 2013). One major reason there are increasing numbers of street children in Ghana may be the presence of economic hardship (UNICEF, 2009). Street children engaging in juvenile delinquency has also been on the increase in the Ghanaian society in spite of efforts made by government and other religious groups to curb it (Hussein, 2008). Delinquency among street children is a social problem which does not only threaten the socio-economic life of Ghanaians but also, a national security threat in Ghana (Hammond, 2013).

Within the Kumasi Metropolis it is estimated that there are over one thousand children living in the street. The Department of Social Welfare estimated there are about 1500 street children in the Kumasi Metropolis (Munyako, 2012). These children have several security challenges reported to the Regional Security Coordination Council. Street homes have negative implications on national security because government over the years had to spend more in providing security for such individuals. The existence of street children in the major streets in the Kumasi Metropolis is a social phenomenon that threatens the region's security. Mostly, children living in street homes commit crime, but due to lack of proper address and location to their place of residence, the police are unable to locate and this affects the arrest of such children and individuals (Neumeyer, 2011). People living in street homes engage in all kind of criminal activities including drug abuse, robbery, rape and violent crimes. According to Thomas (2013) street homes have security implication which undermines economic growth, social and educational factors that either trigger or exacerbate other problems. Although each child has his/her own experience and reason that drove him/her to the streets, the reasons contributing to this phenomenon in Kumasi and the possible security threats have no much research backing. However, there is scanty literatures backing the concerns of security threat that street children poses within the Kumasi Metropolis. It is on these grounds that the study seeks to investigate street homes and its effect on national security in Kumasi Metropolis. The main objective of this study was to investigate street homes and its security implications. Specifically, examining the risk factors associated with street homes, the national security implications of street homes, investigating children living in street homes being provided with their basic security needs by persons/institutions and finding out whether children living in street homes have knowledge on national policies that protects their right.

\section{Literature Review}

Most children who leave home to live on the street come from slums or low cost housing, both of which are areas of high illiteracy, drug use and unemployment (Siegelbaum, 2012). Children usually transfer their lives to the streets through a gradual process; they only stay on the street a night or two for the first time and gradually they spend more time away from home until they do not return (Bose, 2012). Once on the streets, children sometimes find out that their living conditions, physical and mental health is better than at home; however, this fact speaks to the poor conditions of their homes rather than good conditions in the street. Street conditions are far from child-friendliness. Once they leave home, many children in street homes move around often because of the fear that their relatives will find them and force them to return home. Rapid and unsustainable urbanization in the post-colonial period, which led to entrenched urban poverty in cities such as Nairobi, Kisumu and Mombasa is an underlying cause of child homelessness (Abari \& Audu, 2013). Rural-urban migration broke up extended families which had previously acted as a support network, taking care of children in cases of abuse, neglect and abandonment. The United Nations Office on Drugs and Crime has reported that glue sniffing is at the core of "street culture" in Nairobi, and that the majority of children in street homes in the cities are habitual solvent users. Research conducted by Cottrell-Boyce for the African Journal of Drug and Alcohol Studies found that glue sniffing amongst Kenyan children in street homes were primarily functional, dulling the senses against the hardship of life on the street but it also provided a link to the support structure of the 'street family' as a potent symbol of shared experience (Naik et al., 2011). Bangladesh is a poor country. Almost half of its population is poor. Following this, there are many 
children in street homes who have to suffer. They do not go to school instead they sell on the street because their parents earn less money or do not work. About four million children live as children in street homes in Bangladesh. It is estimated that there are over 600,000 children in street homes living in Bangladesh, $75 \%$ of them live in the nation's capital, Dhaka (UNICEF, 2008). In a country ranked 138th on the Human Development Index and where 50\% of the population is living below the poverty line, these children represent the absolute lowest level in the social hierarchy in the world's most densely populated nation. However, the population in the country increased and the number of children in street homes has also increased to four million (UNICEF, 2008).

India has an estimated one million or more children in street homes in each of the following cities: New Delhi, Kolkata, and Mumbai. It is more common for children in street homes to be males and have an average age of fourteen (UNICEF, 2008). There were over 170,000 children in street homes living in Indonesia. In 2000, about 1,600 children were living on the streets of Yogyakarta. Approximately 500 of these children were girls between the ages of 4-16 years. Many children began living on the street after the 1997 financial crisis in Indonesia (UNICEF, 2008). Girls living on the street face more difficulties than boys in Indonesia. Girls on the street are often abused by the street boys because of the patriarchal nature of the culture. They abuse girls, refuse to acknowledge them as children in street homes but liken them to prostitute. Many girls become dependent on their boyfriends since they receive material support in exchange for sex (Berezina, 2007). The children in street homes in Indonesia are seen as a public nuisance since they are detained, subjected to verbal and physical abuse, their means of livelihood (guitars for busking, goods for sale) confiscated, and some been shot attempting to flee from the police. The number of children in street homes in Pakistan is estimated to be between 1.2 million and 1.5 million (UNICEF, 2008). Meaning the country has one of the world's largest children in street homes population.

Work is a very important aspect of the lives of children living on the street. Unfortunately, working conditions for children in street homes are often very poor because they are confined to working in the informal sector, which is unregulated by the government. In Bombay, 50,000 children are illegally employed by 11,750 hotels, restaurants, canteens, tea shops, and eating places. Because children in street homes lack protection from the family and the law, employers often exploit them, making them virtual prisoners, sometimes withholding their pay, and abusing them. Employers that do not maltreat the children often will not hire them because they are seen as too great of a risk (Kombarakaran, 2004). One of the most common economic activities done by the children is scavenging for recyclable materials, such as plastics, papers and metals. Other jobs include washing of cars; petty vending, selling small items such as balloons or sweets, newspapers or flowers, begging, shining shoes, working in small hotels, working on construction sites and working on roadside stalls or repairing of shops (Singh, 2011). Children in street homes especially the older children are also sometimes seen engaging in activities such as stealing, pick-pocketing, drug-peddling and prostitution, though this is only of a small proportion. Most of the children in street homes work between eight to ten hours total each day in their various economic activities.

Children in street homes are vulnerable among low-income children because they do not have the support structures that other children normally have, namely families, the psychological and monetary support they offer (Chatterjee, 2012). Thus, children in street homes adopt strategies to cope with the harsh realities of their lives. For many, these strategies include developing a tough exterior and strong independence to hide their vulnerability. Children in street homes live in survival-mode, constantly having to be aware of their surroundings and fight for their safety (Siegelbaum, 2012). While the majority of children in street homes in India have been found to use positive coping mechanisms to deal with the stress of their lives, some choose maladaptive strategies, such as drinking of alcohol, usage of drugs and visiting prostitutes. When questioned about their substance use, many children in street homes in Bombay reported that the cause was frustration associated with living on the street or conflicts in their family which caused them to leave home (Bose, 2012). Fortunately, children in street homes are not entirely on their own. Many form groups with other children to protect themselves. These groups normally have a leader and specific territory; unfortunately, though these groups bring safety to most, younger children are sometimes used by the leader to steal or do other illegal activities (Bose, 2012). Children in street homes in Bombay reported that they mostly rely on their friends for help when they are sick, go for money when they run out, and gain information about work when they need a job. Children in street homes spend much of their free time with their friends, often going to the movies (Siegelbaum, 2012).

While various governments in other countries have implemented programs to deal with children in street homes, the general solution involves placing the children into orphanage homes, juvenile homes, or correctional institutions. Efforts have been made by various governments to support or partner with Non-Governmental Organizations (NGOs). There are four categories of how societies deal with children in street homes: Correctional model, Rehabilitative model, Outreach strategies, and preventive approach (UNICEF, 2008). The Correctional model is primarily used by government and the police. They see children as a public nuisance and risk to security of the general public. The objective of this model would be to protect the public and help keep the children away from a criminal life. The methods this model uses to keep the children away from the criminal lives are the juvenile justice system and specific institutions. The Rehabilitative model is supported by churches and NGOs. The view of this model is that children in street homes are damaged and in need of help. 
The objective of this model is to rehabilitate children into mainstream society. The methods used to keep children from going back to the streets are education, drug detoxification programs, and provision of a safe family-like environment. The Outreach strategy is supported by street teachers, NGOs, and church organizations. This strategy sees children in street homes as oppressed individuals in need of support from their communities. The objective of the Outreach strategy is to empower the children on street homes by providing outreach education and training to support them. The preventive approach is supported by NGOs, the coalition of children in street homes and lobbying governments. They see children in street homes as having poor circumstances from negative social and economic forces.

\section{Theoretical Framework}

In this article, the family system perspective will be adopted. The problem of children living on the street is facilitated by parents, the people they live with and family members. Until the advent of initiatives to address children on street homes and domestic violence in the last quarter of the 20th century, it remained a private matter, hidden from public eye (WHO, 2002). This study explains street homes by the use of Family System Theory (FST). This theory contends among others that, the family is seen as a system composed of many members who play useful roles which are guided by rules specifying who should do what at what time. When these roles are performed as expected, the family becomes functional and keeps homeostasis. The import of this is that, the phenomenon of street homes occurs in the family in which performance of roles and rules become blurred. This tends to create enmeshed roles, rules and organized boundaries which make the family system dysfunctional. Thus, in such a dysfunctional family, the expectation of other family members to provide caregiving support services to the street children becomes a challenge since members do not perform their expected roles.

\section{Conceptual Framework}

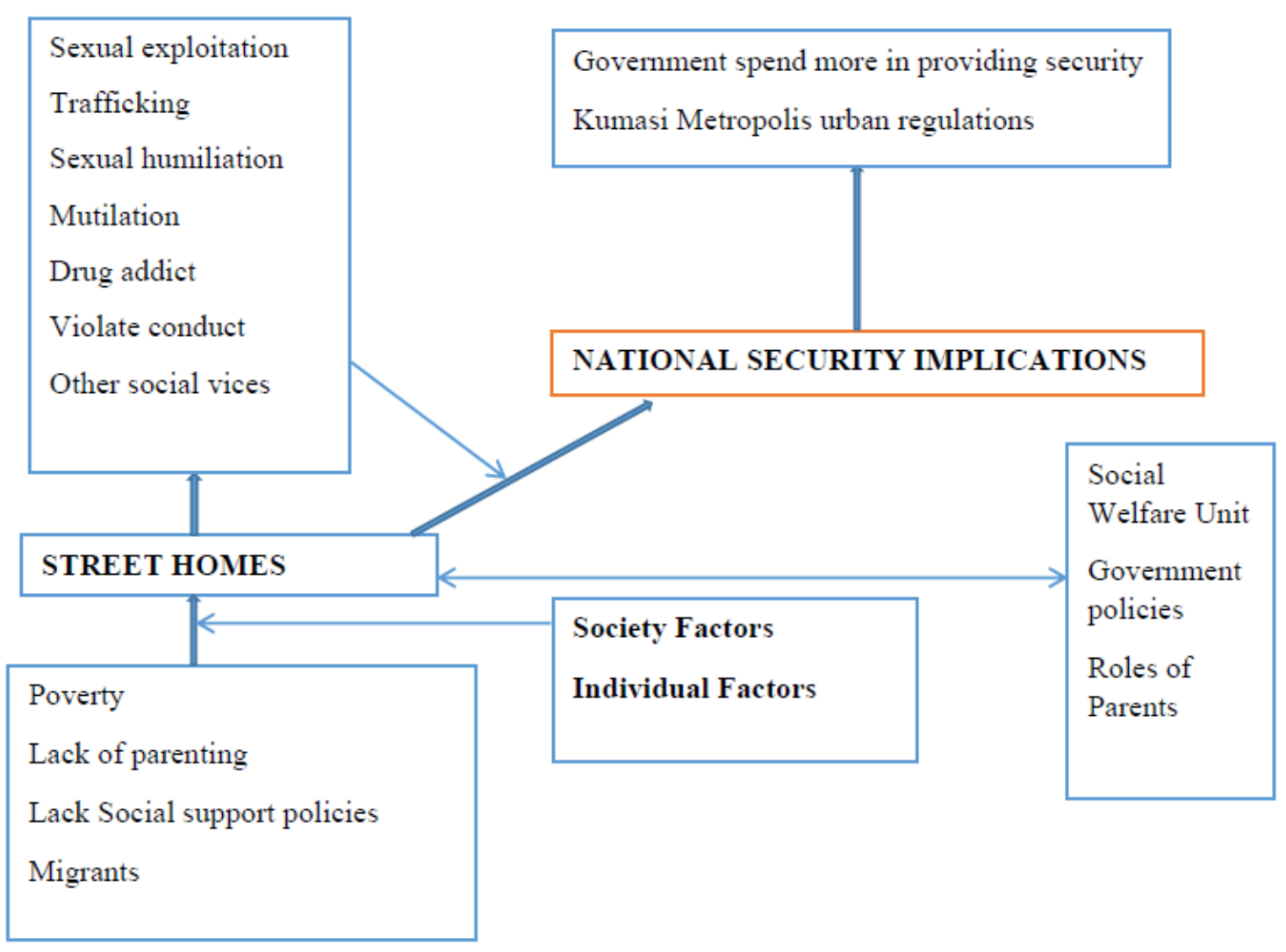

Figure 1. Conceptual framework of street homes and its security implications

Source: Researchers' own construct, 2018

The researchers hypothesized that street homes have several implications to national security when individual living in the streets engage in or are victims of sexual exploitation, trafficking, sexual humiliation, mutilation, drug abuse, violent conduct or other social vices. The cases as expressed with regards to people living in the street homes would imply that the government would have to spend more in providing security to protect people living in street homes or the general public who may suffer as victims of crimes committed by people living in street homes. Equally, the Kumasi Metropolis would 
have spent more on cities regulations to provide better protection for the citizens within the metropolis. It is however, a collective role and collective effort of all units of society including social welfare unit, government policies and roles of parents to reduce the number of people living on the street. If parents put in much effort they would be able to provide homes and better accommodation. The government should also provide more funding to the social welfare unit to support families living in street homes.

By street homes, it implied families that make temporal structures using rubbers, clothing, boxes and plywood in front of shops and stores in the Central Business District (CBD) in the Kumasi Metropolis and spend their night between non-working hours. Street home refers to individuals who spend the night in front of shops and stores mostly between the hours of $10 \mathrm{pm}$ at night to $4 \mathrm{am}$ in the morning. Such families have no permanent structures or residence to live in but spend the night in front of shops and stores in the CBDs after the shop owners have closed from their daily activities.

\section{Methodology}

This study adopted the social survey design to provide empirical data. This design was adopted because it allowed the researchers to study the objectives in their natural setting. This design aided in the collection of primary data. This study adopted a quantitative approach. The quantitative approach was employed for the collection, analysis and presentation of data. Primary and secondary sources of information and ideas were the main sources of data for the study. The probability sampling method was utilized for the research. Specifically, the study used the systematic and simple random or chance sampling technique. Systematic sampling and simple random or chance sampling were utilized to select respondents from the general population of children living on the street. Effectively sampling using this technique, study first identified the major streets in the CBD in Kumasi Metropolis where most families spend the night at. In all, 24 streets were identified with individuals living on the street homes, that is, structures constructed in front of shops and stores during night hours of $10 \mathrm{pm}$ to $4 \mathrm{pm}$. The major streets identified as places for streets homes included; streets at Adum, Railways, Asafo, Ashtown, Fanti New Town, Roman Hill, Alaba, Aboaboa Station, Dr. Mensah, Zongo Police Station, road from Ashtown to Krofrom, and road from Adum to Bantama and sub-streets within these areas. The study then systematically selected the first street which was Roman Hill to Railways street. After selecting this street, the researcher randomly selected the individual families in the street to be a part of the sampled population. The researcher then moved to two streets between the first selected streets and to the next street that was used as the subsequent sampling frame for selection of respondents. This was repeated until the desired sample size of respondents was selected for both the children and parents living in street homes. The systematic sampling technique and simple random sampling were adopted because it showed the true representative sample of the larger population. This study made use of 200 respondents which was made up of 60 parents, 20 police officers and 120 children living in street homes. For the personnel, the study used the simple random sampling technique to select the respondents from three police stations that have jurisdiction within the CBD. These were the Kumasi Central Police Station, Zongo Police Station and Railway Police Station. The size of the sample was of the fact that it formed a true reflection of the population. A structured interview questionnaire was used as the instrument for the data collection. The choice of structured interview questionnaire enabled respondents who cannot read to also form part of the study, in the sense that the researcher read the questions to the respondents. These questions were also used to meet the objectives of the study.

The structured interview questionnaire was designed on risk factors considered to be a threat to children living in street homes. This was done using a likert scale ranging from 1=strongly disagree (SD), $2=$ disagree (D), $3=$ neutral (N) 4=agree (A), 5=strongly agree (SA). The respondents were asked to indicate their level of agreement in respect to the set of statements considered as risk factors to children living in street homes. These risk factors included; "Victims of rape, Engagement in all social vices, Dropout of school, Engagement in child labour, Health problems due to mosquitoes, Teenage pregnancy, Victims of child prostitution, Engagement in robbery and stealing, Engagement in drug addiction, Environment pollution and Influence by bad peers". Using the scale of $1=$ strongly disagreed (SD) to 5=strongly agreed (SA), the respondents' responses were ranked using average $(\bar{x})$ scores to imply that an average $(\bar{x})$ of less than 2.5 means that the respondents disagreed with that particular statement as a risk factor associated with children living in street homes, an average $(\bar{x})$ score of 2.5 to 3.4 implied that they were uncertain or neutral with regards to the statement as risk factors associated with children living in street homes and average $(\bar{x})$ score of 3.5 and greater implied that respondents agreed that such statement were seen as risk factors associated with children living in street homes. Both parents and children were made to answer similar questionnaire on this objectives since they had better experience on the risk factors they were exposed to as they lived on street home.

The structured interview questionnaire was designed using likert scale for children who had some knowledge on national policies that protected their interest. Using a likert scale ranging from $1=$ strongly disagreed (SD) to $5=$ strongly agreed (SA), children who had knowledge on national policies that protected their rights were ranked using an average $(\bar{x})$ score of less than 2.5 to imply that the children had no knowledge on such national policy, average $(\bar{x})$ score 2.5 to 3.4 implied that they were uncertain or neutral with regards to the statement of national policy protecting their rights 
and an average $(\bar{x})$ score of 3.5 which implied that most children had high level of knowledge with regards to the national policy that protected their rights. The factors scaled under these set of questions included; "Parents are supposed to provide descent accommodation for their children, It is parent/s responsibility to provide the health care of their children, Parents are required by law not to abuse their children, Parents are not to engage children in child labour, Children are supposed to enjoy free basic school, Parents are responsible to see to it that their children attend school regularly, Children can report their parents to the police for not providing them with their security and protection, Children can report parents for leaving them on the street, I know the children's act, I know the juvenile's act, Children can be sentenced to prison, Children can report abuse cases to police". The policies that most children were aware of had an average score of 3.5 and above while those that the children had no knowledge about had an average score of 3.4 and less.

Equally, a likert scale was adopted to enquire from police and security personnel regarding their views on security implications of street children within the Kumasi Metropolis. The personnel were made to answer questions pertaining to security since that was their field. Equally, the personnel had better views regarding issues of security. Here, respondents were made to indicate their views on some statements considered as security implications of street homes. The study used a scale ranging from $1=$ strongly disagree (SD) to $5=$ strongly agree (SA); to rank factors such as "Street children engage in child robbery/stealing, Street children are security threat the general public, Street children engage in child prostitution, Street children engage in drugs, Street children find themselves in violent crimes, Street children commit crime against innocent citizens, Street children cause damages to public facilities, Street children are mostly school dropout, Street children perpetrate poverty, They are used by adults for child trafficking, Street children create tension in areas they live, They are source of anxiety and fears to the general public" as security implication in Kumasi Metropolis. The average $(\bar{x})$ score were ranked such that an average score less than 2.5 implied that the police and security personnel disagreed to the statements as security implication, average $(\bar{x})$ score of 2.5 to 3.4 implied that the personnel were neutral and average $(\bar{x})$ score of 3.5 and above implied that personnel agreed that the statements were seen as security implications associated with children living in street homes in Kumasi.

The data collected via interviewing questionnaire was processed in order to make them amenable to analysis. Data processing consisted of a number of closely related operations; coding, editing, data entry and data analysis. Coding allowed the researcher to provide coding frame and coding scheme in assigning themes and numerals for responses from the interviewing questionnaire. Editing was done at two stages: first at the fieldwork stage and after the field. The purpose of this was to examine the data and find out whether all the questions have been answered correctly and that there were no inconsistencies in responses. Data collected from the field was then entered into the Statistical Package for the Social Sciences (SPSS) by the researchers. Variables were defined in the variable view phase of the SPSS programme while data was entered into the data view of the software programme to create a data file. Descriptive statistics such as tables and charts were used in the analysis and presentation of data. The primary area of ethical issues that the researchers considered incorporated the informed consent, invasion of privacy, anonymity and confidentiality.

\section{Results of the Study}

This study sought to identify the risk factors associated with street homes, to investigate the national security implications of street homes, to establish from children living on street homes persons/institutions that provide their basic needs and to find out whether children living on street homes have knowledge on national policies that protects their right.

\subsection{Risk Factors Associated with Street Homes}

This study sought to identify the risk factors associated with street homes. The findings of the study revealed that majority of the respondents rated the issue of school dropout as the most common risk factor associated with people living in street homes. The study found that 149 respondents out of 180 children and parents living in street homes agreed that they were victims of school dropout. This recorded a mean score of 4.63 which implied that most people in street homes agreed that children in street homes were more likely to drop-out of school. The study finding confirmed the views of Bucher (2013) that children who live on the street were noted of truancy and school dropout. The second most common risk factor associated with street homes according to respondents was the incidence of rape and sexual assault. It was found that 138 respondents agreed that most people living in street homes had high record of rape compared to family in housing settlement and permanent place of residence. This recorded a mean score of 4.59 which implied that majority of the people living in street homes agreed that one major risk factor was that of rape and sexual assault compared to people living in houses and well enclosed structured. The result of the study implied that most people in street homes were more likely to be raped than those living in permanent enclosed place of residence. The argument is that the structures in which families that live in street homes stay in provides an easy access and entry to perpetrators. In the views of Ennew \& Jill (2013) people living in the street were 8 times more likely to experience rape and other forms of sexual assault than those not living in streets. Third risk factor according to respondents was that children were more likely to engage in child labour. The study found that 145 
respondents agreed that one risk factor for people living in street homes was their engagement in child labour. This recorded a mean score of 4.43 which implied that people living in street homes were faced with the risk of engaging children in child labour. The result of the study confirmed the views of Burt et al. (2013) that incidence of child labour was common among children who spend more time on the street than children who are in school or have houses to live in. Ranking the risk factors of street homes according to the respondents, the risk factor of having health problems due to mosquitoes placed 4th with a mean score of 4.38 , teenage pregnancy was 5 th with mean score of 4.23 , environment pollution was placed 6th with mean score of 4.13 and influence from bad peers placed 7th with a mean score of 4.05. The results of the study implied that respondents agreed that these were risk factors associated with street homes. The results of the study confirmed the views of Hussein (2008); Chatterjee (2012) and Hammond (2013) that people living in street homes were at risk to many social menaces. According to Chatterjee (2012), issues of teenage pregnancy, health related problems, bad peer influence were all common among children living in street homes. The respondents agreed to some risk factors associated with street homes and these included; engagement in robbery and stealing with mean of 3.21, victims of child prostitution which had mean score of 2.43, engagement in drug addiction with mean of 3.56, and engagement in all social vices which also recorded a mean score of 2.13. The results of the study implied that people living in street homes do not commit crimes such as child prostitution, robbery and stealing, drug addiction and all social vices (See table 1). Respondents argued that they were rather victims of these crimes than perpetrators of social vices since most of them were vulnerable and people took advantage of the position and place of residence to commit all kinds of social vices against them. The results of the study implied that risk factors of people living in street homes included people trying to use them for child prostitution, criminals stealing their properties, drug addict attacking them and many other social vices which most people living in street homes had always been victims of. The findings of the concurred the views of Neumeyer (2011) that the most appealing problem of street home is that the phenomenon is far becoming a major global security threat and criminals perpetrate all kinds of crimes against persons living in street homes. Naik et al. (2011) also noted that reports across the major towns and cities showed that street home is becoming alarming and both boys and girls are all victims of abuse, sexual exploitation, trafficking, sexual humiliation and mutilation.

Table 1. Descriptive statistical analysis on Risk factors associated with street homes (views of children and parents: $\mathrm{N}=180$ )

\begin{tabular}{lll}
\hline STATEMENT & Mean & St. Dev. \\
\hline Victims of rape and sexual assault & 4.59 & 1.13 \\
Engagement in all social vices & 2.13 & 1.03 \\
Dropout of school & 4.63 & 1.05 \\
Engagement in child labour & 4.42 & 1.43 \\
Health problem due to mosquitoes & 4.38 & $11^{\text {th }}$ \\
Teenage pregnancy & 4.23 & $1^{\text {st }}$ \\
Victims of child prostitution & 2.43 & $3^{\text {rd }}$ \\
Engagement in robbery and stealing & 3.21 & 1.81 \\
Engagement in drug addiction & 3.56 & $4^{\text {th }}$ \\
Environment pollution & 4.13 & 1.70 \\
Influence by bad peers & $5^{\text {th }}$ & 1.53 \\
\end{tabular}

\section{Source: Field Data, 2018}

\subsection{Person/Institutions that Provide the Basic Needs of Street Children}

The study sought to establish from street children, persons or institutions that provide their basic needs. The findings of the study showed that $45 \%$ of children in street homes indicated that their mothers provide them with their basic needs, $5 \%$ of the children in street homes revealed that their fathers provide them with their basic needs, $31 \%$ of the children in street homes who were involved in this stated that they provide their basic needs by themselves and no one provided their basic needs for them. It was also found that $3 \%$ of the children living in street homes had both parents available in providing them with their basic needs and $16 \%$ of the children in street homes had to rely on their friends, relatives and other sources to meet their basic needs (See figure 1). With children who provide their basic needs by themselves it implied that it has national security implication and a cause of worry to society because children would then have to engage in child labour to provide for their basic needs. In the views of Fradkov (2007), the intricate idea of the child labour issue requires a multifaceted approach around the world as most children in street homes work.

Further investigation from respondents regarding the institutions that provide children living in street homes with their basic needs, the findings of the study showed that $25 \%$ of children in street homes argued that the police is one state institution that provided them with their basic need such as security, $2 \%$ stated that they had social welfare department that provided them with some needs such as counseling. The study further found that $12 \%$ of children living in street homes had received some support in terms of provision of their basic needs through NGOs such as shelter and food. This confirmed the views of Hammond (2013); Munyako (2012) that NGOs have been supportive in addressing street children 
in most urban centres in Africa. It also implied that families that lived in street homes in Kumasi could rely on the support from NGOs to provide them with shelter or income that could help them acquire places of residence rather than staying in the streets. It was also found that $7 \%$ of the children stated that religious bodies had provided them with their basic needs such as food and clothing and only $1 \%$ of children in street homes had support from the children homes in the form of shelter, food, education and health (See figure 2). The study found that majority of the children living in street homes had never received any support from any institutions in terms of provision of any of their basic needs. The results of the study implied that government, civil society organization, Non-Governmental Organizations had not done much to support children living in street homes. This was seen as a major national security concern as children living in street homes had to make provisions for their basic needs on their own and that of the people around them and not state institutions. The consequences of this was that children in street homes had to engage in all kinds of economic activities that could earn them an income in order to meet their basic needs. On a national security scale, the harm to children in the work to provide their basic need undermines a nation's social and monetary advance far into the future (ILO, 1996). With national security survival ending up more reliant on brains than dark colored on children working to provide their basic needs rather than schooling, decreasing child work mishandles is a fundamental component of national security advancement. Additionally, a social welfare concern, as noted by Wheat (2002), communicated stun at the diligent work children occurs in few sections of Ghana. As indicated by Wheat (2002) children living in street homes and grown-ups working in a portion of the hardest conditions possible to meet their basic need is a national security concern. In this manner, Wheat (2002) stated that children stand an extraordinary danger of working in environment that poses national security threat.

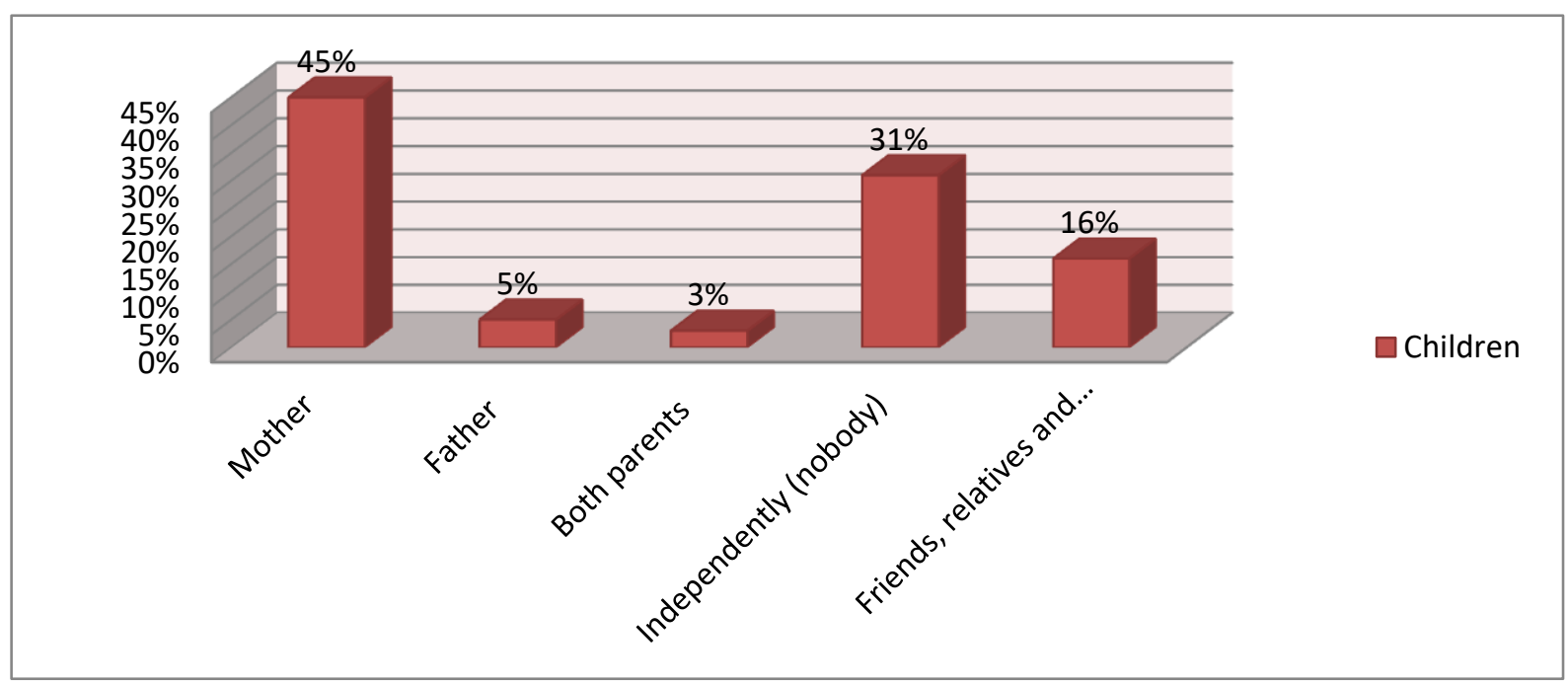

Figure 2. Persons that provide children living in street homes with their basic needs

Source: Field Data, 2018

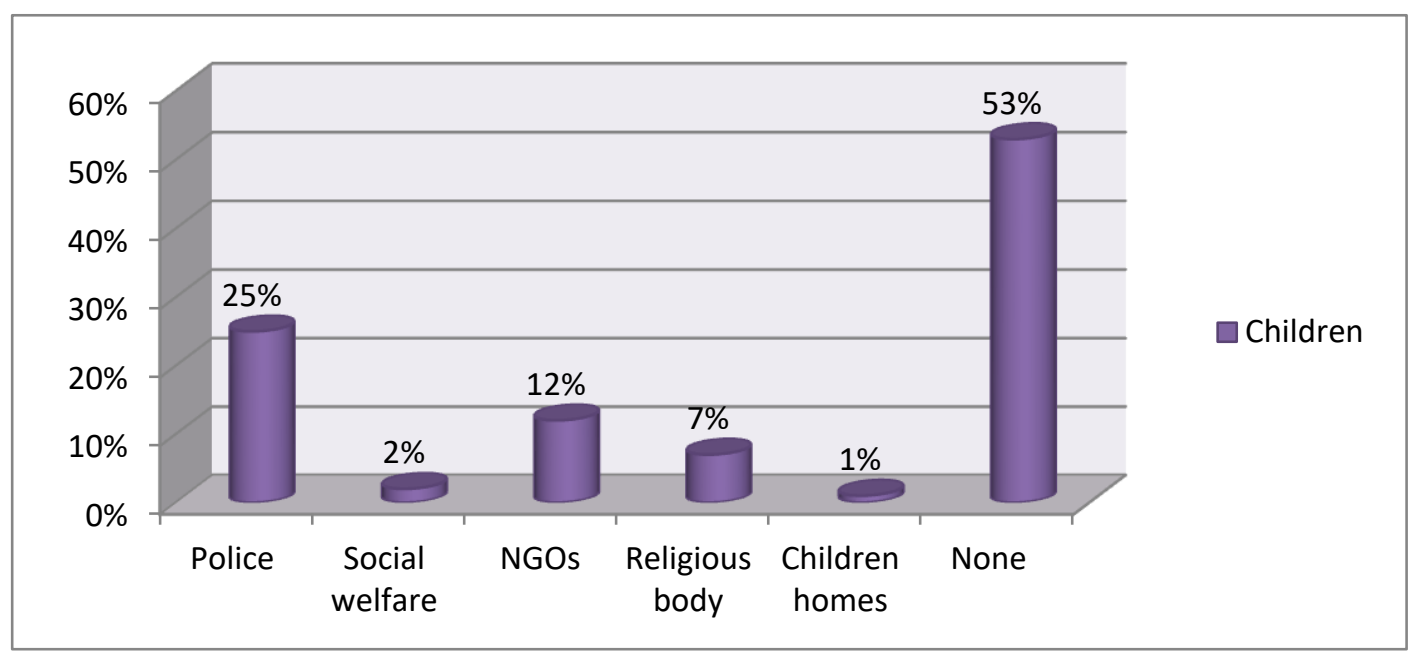

Figure 3. State institutions that provide children in street homes with their basic needs

Source: Field Data, 2018 


\subsection{Knowledge of Children in Street Homes on National Policies that Protect Their Rights}

The study sought to find out from children their knowledge on national policies that protect their rights. Findings of the study established that found that $83 \%$ of the children had no knowledge on national policies that protect their rights. Only $17 \%$ of the children showed some level of awareness of national policies on their right (See figure 3). The result of the study implied that children living in street homes had no knowledge on any national policies that seek to protect their right. This means that children in street homes were ignorant about the government or state protection. The consequence of this ignorance on the part of children living in the street implied that people could abuse them without the children reporting to the police. It also implied that children in the street homes could also engage in criminal activities which have national security consequence.

Table 2. Descriptive statistical analysis on children awareness of national policies that protects their right $(\mathrm{N}=20)$

\begin{tabular}{|c|c|c|c|c|c|}
\hline Right of children & Not at all & Have heard of it & Aware & Mean & Rank \\
\hline $\begin{array}{l}\text { Parent/s are supposed to provide descent accommodation for } \\
\text { their children }\end{array}$ & 13 & 4 & 3 & 1.36 & $6^{\text {th }}$ \\
\hline $\begin{array}{l}\text { It is parent/s responsibility to provide the health needs of } \\
\text { their children }\end{array}$ & 4 & 6 & 10 & 2.45 & $5^{\text {th }}$ \\
\hline Parent/s are required by law not to abuse children & 18 & 2 & 0 & 1.01 & $11^{\text {th }}$ \\
\hline Parent/s are not to engage children in child labour & 17 & 2 & 1 & 1.06 & $10^{\text {th }}$ \\
\hline Children are supposed to attend basic school for free & 3 & 5 & 12 & 2.76 & $1^{\mathrm{st}}$ \\
\hline $\begin{array}{l}\text { Parent/s are responsible to see to it that their children attend } \\
\text { school regularly }\end{array}$ & 5 & 7 & 9 & 2.65 & $2^{\text {nd }}$ \\
\hline $\begin{array}{l}\text { Children can report their parent/s to the police for not } \\
\text { providing them with their security and protection }\end{array}$ & 10 & 7 & 3 & 1.34 & $7^{\text {th }}$ \\
\hline Children can report parent/s for leaving them on the street & 16 & 3 & 1 & 1.15 & $8^{\text {th }}$ \\
\hline I know the children's act & 19 & 1 & 0 & 1.11 & $9^{\text {th }}$ \\
\hline I know the juvenile's act & 20 & 0 & 0 & 1.00 & \\
\hline Children can be sentenced to prison & 3 & 5 & 12 & 2.57 & $3^{\text {rd }}$ \\
\hline Children can report abuse cases to police & 3 & 6 & 11 & 2.53 & $4^{\text {th }}$ \\
\hline
\end{tabular}

Source: Field Data, 2018 (20 Children who indicated that they were aware of policies that protect their rights)

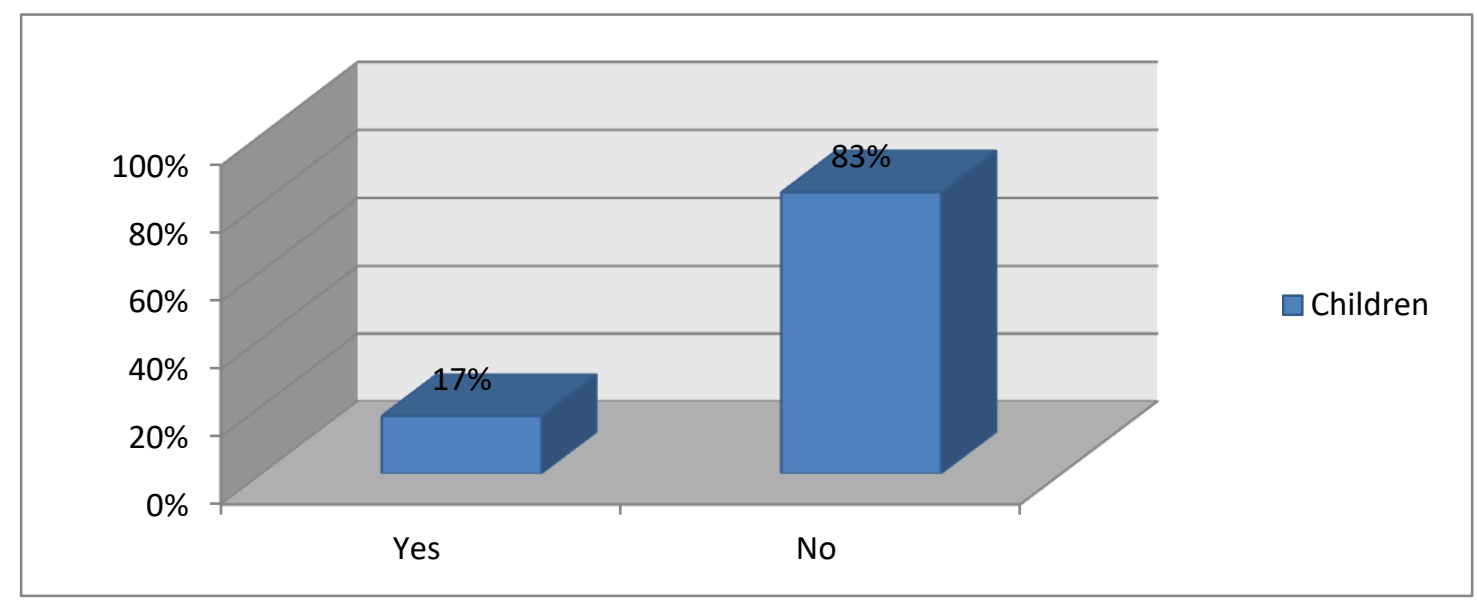

Figure 4. Respondents' awareness of national policies that protect the rights of children

Source: Field Data, 2018

With only $17 \%$ indicating that they were aware of the national policies protecting them, the study sought to inquire from these children which policies they were familiar with. The study found that although $17 \%$ of children living in street homes were aware of national policies that protect the right of children. Most children demonstrated minimal awareness of these rights (See figure 3). As presented above, the study results implied that most children were aware of issues such as attending free basic school and that their parent/s were responsible to see to it that they attend school regularly. This implied that children in the street knew of their right to basic education but lack the support and encourage from parents to ensure that they were in school which left most of the children in street homes uneducated. The study also found that children in street homes were aware of the fact that they could be sentenced to prison if they commit crime and that they had the right to report to the police abuse against them. This result implied that some children in street homes were aware of the fact that there were laws that regulate their behavior and that it was against the law to commit crime regardless of one's age. The children were also aware that it was the parent/s responsibility to provide them with their health needs. 
Some important national policies that protect the rights of children in street homes that the children were not aware of included the Children's Act and the Juvenile Act. Majority of the children in street homes who stated they were aware of national policies that protected their rights did not have knowledge on the two most important national policies and acts that protects them. This showed poor level of awareness among children living in street homes on national policies that protected their rights. The lack of awareness amongst children in street homes on policies that protected their rights implied that such children could be abused and exploited without them knowing or seeking for proper redress. Hence, the results of the study clearly showed that street homes had serious national security implications which needs to be addressed. The children then again did not know that their parent/s are required by law not to abuse them. In the views of Benitez (2007) children globally are abused due to their lack of knowledge on policies and laws that protect children from abuse.

\subsection{Security Implications of Street Homes}

The study sought to investigate national security implications of street homes. Among the factors considered as national security implications and threat posed by people living in street homes, the study found that security personnel considered that children in street homes find themselves in violent crimes which was seen as the common national security implication by people living in street homes and this recorded a mean score of 4.75 . The second most common national security implication of street homes was that they commit crime against innocent citizens and this recorded a mean score of 4.69. The third factor considered as national security implication of street homes according to security personnel was that children in street homes cause damages to public facilities and this also recorded a mean score of 4.67 (See table 3). The result of the study implied that people in street homes have several national security implications. In the views of Patt, Abramov \& Loselerich (2010) people in street homes posed a threat to others. Whilst people who lived in street homes may be victims of crimes, they also commit violence and property crimes. From the results of the study, it was found that people who lived in street homes had negative consequences on national security. Other national security implications of people living in street homes included; engagement in drugs which recorded a mean score of 4.42, causes security threat to the general public with mean score of 4.37 , perpetrate property crimes which recorded a mean score of 3.94 , engagement in child trafficking with mean score of 4.18, creation of tension in areas they lived with mean score of 4.10. Security personnel also viewed people who lived in street homes as those more likely to drop out of school with mean score of 4.31. The study further engagement in prostitution also had mean score of 3.13, source of anxiety and fears to the general public also recorded a mean score of 2.24 and engagement in robbery/stealing with a mean score of 3.10 (See table 3). The results of the study showed that street homes had national security implications according to the security personnel. This revealed that people in street homes commit numerous crimes or were victims of crimes. This confirmed the views of Neumeyer (2011) that the most appealing problem of street home is that the phenomenon is far becoming a major global security threat and that reports across the major towns and cities shows that street home is becoming alarming. Naik et al. (2011) found that both boys and girls are all victims of abuse, sexual exploitation, trafficking, sexual humiliation and mutilation.

Table 3. Descriptive statistical analysis on security implications of street homes (Police personnel, N=20)

\begin{tabular}{llll}
\hline STATEMENT & Means & Standard deviation & Ranks \\
\hline Children in street homes engage robbery/stealing & 3.10 & 1.01 & $11^{\text {th }}$ \\
Children in street homes are security threat to the general public & 4.37 & 1.31 & $5^{\text {th }}$ \\
Children in street homes engage in child prostitution & 3.12 & 1.94 & $10^{\text {th }}$ \\
Children in street homes engage in drugs & 4.42 & 1.52 & $4^{\text {th }}$ \\
Children in street homes find themselves in violent crimes & 4.75 & 1.48 & $1^{\text {st }}$ \\
Children in street homes commit crime against innocent citizens & 4.69 & 1.50 & $2^{\text {nd }}$ \\
Children in street homes cause damage to public facilities & 4.67 & 1.32 & $3^{\text {rd }}$ \\
Children in street homes are mostly school dropouts & 4.31 & 1.42 & $6^{\text {th }}$ \\
Children in street homes perpetrate property crime & 3.94 & 1.61 & $9^{\text {th }}$ \\
They are used by adult for child trafficking & 4.18 & 1.51 & $7^{\text {th }}$ \\
Children in street homes create tension in areas they live & 4.10 & 1.74 & $8^{\text {th }}$ \\
They are sources of anxiety and fears to the general public & 2.24 & 1.04 & $12^{\text {th }}$ \\
\hline
\end{tabular}

\section{Source: Field Data, 2018}

\section{Conclusion}

The findings of the study adequately satisfied the research objectives. The study concluded that there were several risk factors associated with street homes. The risk factors included; victims of rape and sexual assault, engagement in all social vices, dropout of school, engagement in child labour, health problems due to mosquitoes, teenage pregnancy, victims of child prostitution, engagement in robbery and stealing, engagement in drug addiction, environmental pollution and influence by bad peers. It was also concluded most children in street homes had their basic needs provided by their mothers. Significant numbers of children living in street homes were depending on themselves. It was also concluded that 
children in street homes had no knowledge on national policies that protect their rights. It was concluded that only few children in street homes were aware of free education and parent's responsibility to make them attend school. It was also concluded that children in street homes were not aware of key important policies and legislations such as the children's Act and Juvenile Act. Although, few children were aware that they could be sentenced for crimes they commit or report to the police against them. Finally, it was concluded that security personnel considered street homes as a major national security threat which had many security implications in the country since children mostly engage in all social vices.

\section{Recommendations}

Based on the findings, the following recommendations were provided to help deal with the menace of street homes and improve upon national security;

Parents should try their possible best to provide accommodation for themselves and their children. Parents who cannot provide accommodation in the cities should consider moving to the rural areas where accommodations are less expensive.

The researcher also recommended that parent/s of children in street homes should ensure that their children are in school. Since basic education is free, parents should not allow their children to engage in child labour but should encourage them to attend school.

The researcher recommended that parent/s should not abuse children living in street homes, children who are abused by parent/s and people around them should report them to the police.

The researcher again recommended that children in street homes should be educated on the national policies that protects them. Civil society organization, NGOs and social advocacy groups should provide citizenship education and should organize programs to teach children on some of the national policies that protect their rights. NGOs should help identify children who had dropout of school due to the fact that they live with the parents in street homes to help educate such children within the Kumasi Metropolis.

The study recommended that the local assembly; Kumasi Metropolis should provide support to street homes children through the social welfare unit. This unit should consider providing accommodation to street home children as its core mandate. The social welfare unit should educate parent/s who live in street homes to take advantage of current government policy on free compulsory basic education and send their children to school.

The researcher recommended that Government should also ensure that parent/s who allow their children engage in child labour are punished. Individuals who engage children in child labour should also be punished by government.

\section{References}

Abari, C. A., \& Audu, D. T. (2013). A study of children in street homes in Kaduna metropolis, Nigeria. IOSR Journal of Humanities and Social Science, 15(1), 44-49. https://doi.org/10.9790/0837-1514449

Agenlli, S. (2016). Street children: A growing urban tragedy, a report for the independent commission on international humanitarian issues, London: Weildenfeld and Nicolsan.

Alston, P. (2008). Hardship in the midst of plenty. New York: The Progress of Nations.

Annoh, K. (1992). Education. Kumasi: KNUST University Press.

Ball, A. M. (2006). And now my soul is hardened: Abandoned children in Soviet Russia, 1918-1930. California: University of California Press.

Beck, B. M. (2009). Recreation and delinquency: Juvenile delinquency and youth crime? California: U.S. Government Publication Office.

Benitez, T. B. (2007). State of the world's children in street homes: Violence, London: Consortium for children in street homes.

Berezina, E. (2007). Victimization and abuse of street children worldwide: Youth Advocate Program International Resource Paper. Retrieved November 30, 2012, from www.unicef.org.

Bose, A. B. (2012). The disadvantaged urban child in India. Innocent occasional papers: Urban Child Series. Retrieved February 20, 2012, from http:Gynet.com

Boswell, J. (2008). The kindness of strangers: The abandonment of children in Western Europe from late antiquity to the renaissance. New York: St. Martin's Press.

Bucher, A. (2013). Recreation and leisure. California: Walsworth Publishing Company.

Burt, C., East, W. N., Shrubsall, F. C., \& Stoddart, W. H. B. (2013). Delinquency and mental defect. Symposium in British Journal of Medical Psychology, 153-193. 
Chatterjee, A. (2012). India: The forgotten children of the cities. Florence, Italy: UNICEF.

Ennew, J. (1994). Street and working children: A guide to planning. London: Save the Children.

Ennew, J., \& Jill, S. (2013). Introduction: Homes, place and space in the construction of street children and street youth. Children, Youth and Environments, 13.

Hammond, J. (2013). Street children in Ghana. A case study of Cape Coast. An unpublished Bachelor of Arts dissertation, Department of Sociology, University of cape coast.

Hussein, N. (2008). The phenomenon of street children: A field research in Greater Cairo. Unpublished PhD dissertation, Ain Shams University.

International Labour Organization. (1996). Child Labour: Refuting the nimble fingers argument. Geneva: ILO.

Kombarakaran, F. A. (2004). Children in street homes of Bombay: Their stresses and strategies of coping. Children and Youth Services Review, 26, 853-871. https://doi.org/10.1016/j.childyouth.2004.02.025

Munyako, A. (2012). The urban child in difficult circumstances, Kenya: Child new comers in the urban jungle. Florence, Italy: Innocenti Studies International Child Developmental Centre, UNICEF.

Naik, P. R., Seema, S. B., Ratnenedra, R. S., \& Abhay, S. N. (2011). Children in street homes of Mumbai: Demographic profile and substance abuse. ebscohost connection. Retrieved April 21, 2013, from http://connection.ebscohost.com

Neumeyer, N. M. (2011). Juvenile delinquent behaviour. New York: John Wiley and Sons.

Patt, M., Abramov, A., \& Loselevich, D. (2010). Prevalence, abuse andexploitation of children in street homes: Children in street homes. Retrieved November 30, 2012, from http: www.Gynet.com

Seigelbaum, L. (2012). “1921: Homeless Children”. Seventeen Moments in Soviet History. James Von Geldern ad Lewis Seigelbaum. Archived from the original on 18 June 2013. Retrieved 30 November 2012.

Singh, A. (2011). Street Children as a Public Health Fiasco. Peace Review, Journal of Social Justice, 23(1), 102-109.

Thomas, S. Y. (2013). Fundamentals of recreation (2nd ed.). Harpes and Row: Library of Congress.

UNICEF. (2000). The US state department annual survey of human rights. Oxford: Oxford University Press.

UNICEF. (2008). British Airways staff visit children in street homes centres in Cairo. Retrieved May 2, 2008, fromwww.unicef.org

UNICEF. (2009). Conference shines a light on potential hazards for street children in South Africa

UNICEF. (2012). Delinquency and its causes. New York: UNICEF.

UNICEF. (2013). Out in the cold: The street children in Mongolia. New York: UNICEF

Wheat, S. (2002). Between a rock and a hard place. Development (Third Quarter), 14-18

WHO. (2002). Monitoring and Evaluation of a Street Children Project: a training package on substance abuse, sexual and reproductive health including HIV/AIDS and STDs. Geneva, Switzerland: Department of Mental Health and Substance Dependence.

\section{Copyrights}

Copyright for this article is retained by the author(s), with first publication rights granted to the journal.

This is an open-access article distributed under the terms and conditions of the Creative Commons Attribution license which permits unrestricted use, distribution, and reproduction in any medium, provided the original work is properly cited. 